\title{
Primary Care Sensitive Hospitalization: users detect flaws on the access to services*
}

\author{
INTERNAÇÕES SENSÍVEIS À ATENÇÃO PRIMÁRIA: USUÁRIOS DETECTAM FALHA NO \\ ACESSO AOS SERVIÇOS
}

\author{
HOSPITALIZACIONES SENSIBLES À LA ATENCIÓN PRIMARIA DE SALUD: LOS \\ USUARIOS PERCIBIRÁN FALLOS EN EL ACCESO A LOS SERVICIOS
}

\author{
Tania Cristina Morais Santa Barbara Rehem¹, Suely Itsuko Ciosak², Emiko Yoshikawa Egry³
}

\begin{abstract}
The aim of this study is to analyze and understand the reasons for the occurrence of sensitive hospitalizations in accordance with users. Qualitative study conducted with users who were

admitted to Pedreira General Hospital, in São Paulo. The data was collected through semi structured interviews and thereafter, transcribed and processed in the electronic program Alceste. When analyzing the content, the access was seized fundamentally as an empirical category, bringing up problems that later deserved, from the Brazilian Ministry of Health, a specific Program to improve the quality and access to primary care. The hierarchical and pyramidal organization shape from the health system in the city of São Paulo can be one of the important aspects for the access matter and established as an important restricting factor in the primary care role in reducing or even preventing the occurrence of these hospitalizations.
\end{abstract}

\section{DESCRIPTORS}

Primary health care

Health evaluation

Access to health services

\section{RESUMO}

O objetivo deste estudo foi analisar e compreender as razões para a ocorrência das internações sensíveis segundo os usuários. Estudo qualitativo, realizado com pacientes que foram internados em um hospital geral do município de São Paulo, Brasil. Os dados foram obtidos por meio de entrevistas semi estruturadas que após transcritas foram processadas no software Alceste. À análise apreendeu-se fundamentalmente como categoria empírica o acesso, trazendo à tona problemas que posteriormente vieram a merecer, por parte do Ministério da Saúde brasileiro, um Programa específico para Melhoria da Qualidade e do Acesso à Atenção Básica. A organização do sistema de saúde no município de São Paulo, de forma hierarquizada e piramidal, pode ser um dos aspectos importantes para a fragilidade do acesso, constituindo-se como fator importante de restrição do papel da atenção primária em reduzir ou até mesmo impedir a ocorrência destas internações.

\section{DESCRITORES}

Atenção primária à saúde

Avaliação em saúde

Acesso aos serviços de saúde

\section{RESUMEN}

El objetivo de este estudio fue analizar y comprender las razones de la aparición de internaciones sensibles, según los usuarios. Estudio cualitativo realizado con pacientes que fueron ingresados en un hospital general de São Paulo, Brasil. Los datos fueron obtenidos a través de las entrevistas semi-estructuradas qué fueran transcritas; se procesaron en el software Alceste. El análisis mostró el acceso como categoría empírica central. El acceso se mostró importante por el Ministerio de Salud de Brasil, que crió un programa específico para mejorar la calidad y acceso a la atención primaria. La organización del sistema de salud en São Paulo, de forma jerárquica y piramidal, puede ser uno de los aspectos importantes de la fragilidad del acceso. Esto se constituye un factor importante de restricción del papel de la atención primaria en la reducción o incluso la prevención ocurrencia de estas hospitalizaciones.

\section{DESCRIPTORES}

Atención primaria de salud

Evaluación en salud

Accesibilidad a los servicios de salud

\footnotetext{
"Extracted from the doctoral thesis " Hospitalizations for primary care sensitive conditions: limits and possibilities of brazilian list of diagnoses. 2011. School of nursing from the University of São Paulo". ' Doctor in Sciences, Adjunct Professor in Nursing at University of Brasília, Brasília, Brazil. ${ }^{2}$ Doctor in Nursing, Full Professor in Collective Health Nursing, Associate Professor at the Collective Health Nursing Department of the Nursing School at São Paulo University. CNPq Productivity Researcher 2. São Paulo, Brazil. ${ }^{3}$ Doctor in Public Health, Full Professor in Collective Health Nursing. Professor of the Collective Health Nursing Department from the Nursing School at São Paulo University. CNPq Productivity Researcher 1A. São Paulo, Brazil.
} 


\section{INTRODUCTION}

In the different health systems there are varying interpretations regarding to the concept and the role of Primary Health Care (PHC). Within those interpretations, the selective PHC deserves attention, characterized as a specific program designated to poor populations and poor regions, the PHC as the primary health care, understood as the one responsible for organizing and making the entrance door to the system work, and the PHC as a strategy to the reorganization of the whole health system. However, it is important to note that the existence of a system where there are one of those categories is very difficult, being the most common the existence of the three coexisting inside one country ${ }^{(1)}$

Initially, the APS was conceived as an entrance door to the health system in Brazil. However, today it is a consensus among managers from the three government spheres, academy, workers and health institutions; that the APS is essential for the health system optimal development and it should have a distinct position in it.

This way, Brazil have been discussing the implantation of health care networks, where the APS has four essential functions inside the system: to be a base; to be resolute; to coordinate care; and to manage the networks ${ }^{(2)}$.

The implantation process of attention nets in Brazil is not new, being planned since the creation of the Brazilian Unified Health System (SUS). However, the discussion in which the APS starts to perform these four essential functions inside the system is more recent and has been happening in many states inside it and as consequence, in many Brazilian municipalities ${ }^{(3)}$.

It is expected that with the new APS role, the attention net implantation will importantly impact the actual assistance model change, making it proactive, integrated, continuous and focused in the promotion and in the maintenance of people's health; responding the present and future demands from the health system.

Those demands, within other aspects, refers to the management of persistent infectious diseases, while an inconclusive agenda, to the accelerated aging process of the population with an important load of chronic diseases and its risk factors; besides the external causes, overall caused by different manifestations of violence ${ }^{(4)}$.

Regarding the chronic conditions, Brazil elaborated the Strategic Actions Plan for Coping with Non-communicable Chronic Diseases (DCNT) to face chronic conditions, from 2011 until 2022. The plan addresses four main groups of diseases: circulation diseases, cancer, chronic respiratory and diabetes ${ }^{(5)}$.
Some diagnosis included in this groups of diseases had already been defined and published by the Health Ministry as part of the Primary Attention Sensible Conditions (ICSAP) ${ }^{(6)}$. The ICSAP is an indicator composed by 19 diagnosis groups in accordance with the international classification of diseases - CID 10, which one primary effective attention would reduce the number of hospitalizations with adequate activities for this level of attention, as: prevention of diseases, early diagnosis, opportune treatment for acute diseases, the control and monitoring chronic diseases ${ }^{(7)}$.

This indicator has been studied in many countries (8-10) $^{-1}$ denominated as Ambulatory Care Sensitive Conditions (ACSC) and in Brazil ${ }^{(11-13)}$ it has been revealing that primary care can act in many ways to reduce or avoid those hospitalizations ${ }^{(7)}$.

Considering the portal that published the ICSAP indicator refers it for assessing the APS access and effectiveness(6), studies including social subjects possibly using this level of care are justified.

Therefore, the present study objective was to analyze and comprehend the reasons for ICSAP occurrence in the selected territory, from the perspective of users.

\section{METHODS}

This is a descriptive study, with a qualitative approach, performed in the health micro region of Ademar City, in the City of São Paulo (SP). The micro region choice was due to its performance in a health local system that integrates primary care services; the ones with medium complexity and some high complexity services, constitutes a privileged scenario for the ICSAP analysis.

The sample was constituted by hospitalized users from the General Hospital of Pedreira (HGP) located in Ademar City, in 2008. They had main ICSAP diagnose, one of the sensitive conditions to the PHC, in the Hospital Authorization for Hospitalization (AIH) as well as in the high medical report in the medical chart, independent of gender and age.

The empiric data obtainment was through individual semi structured interviews with two blocs of questions; the first referring to socio demographic variables and the second contemplating the following directing questions: Can you tell me how this disease started, which led you to hospitalization in the General Hospital of Pedreira in 2008 , and by which services have you been through? From your point of view, what were the reasons that started this hospitalization?

The interviews were conducted in a two-month period in 2010 at the user's house after previous scheduling 
by a telephone number available in their medical charts; they were recorded and unrecorded, keeping it loyal to its content.

After the transcription, the material was analyzed by an electronic program Alceste - Lexical Analysis by Content of a Text Segment Conjunct - that has been used in diverse research in Brazil and Europe. It aims to find basic information in a text through a statistical treatment of its elements. Thus, it is a software that allows automatic analysis of research open questions, to quantify a text for extraction of the most significant structures $^{(14,15)}$.

The present study was approved by the Research Ethics Committee from the Nursing School of São Paulo University (process n.o 860/2009); and the General Hospital of Pedreira (register CEP-HGP:01/1/P), accompanied of the Free and Informed Consent Term (TCLE) in accordance with the CONEP resolution $n$. o $196 / 1996$.

\section{RESULTS}

Based in the analysis of the medical charts and $\mathrm{AlH}$ analysis, 104 users met the inclusion criteria defined for participation in the study. However, from those, only seven users were found.

The reasons for not finding the other users were: death; address change when looking for the users at their residence; telephone number change considering the avwailable number for hospitalization at the HGP and residence not found.

From the seven participating users, five were female; most of them were married (four people), and four were between the age group of $\geq 27$ to $<47$, two between the age group of $\geq 19$ to $\leq 26$ and one $\geq 47$ years old. Three users worked as cleaning ladies, one was unemployed, two were away from work due to sickness and two were lady of the house. Incomplete middle school was predominant (four people). One person had completed middle school and another had high school incomplete. Only one person had completed high school.

The results obtained with Alceste helped in the data interpretation as it brought the list of words with characteristic vocabulary from each class; frequent word combinations and complete text from the original content from each class; it means the fragments of speeches. Based on that, when analyzing their narratives, it was fundamentally apprehended the ACCESS as empiric category (Chart 1).
Chart 1 - Empirical category and the speech content of users, São Paulo, Brazil, 2010.

\section{ACCESS}

[...] my kids go to the UBS, but to schedule an appointment takes time. The woman has to come, although she has not been coming home, and then we have to run after [...] (male user)

[...] I had to run after and to go there and argue to be attended. Then she said: you have to schedule an appointment. I said: but if someone would go home, they would schedule it. (male user)

[...] I have trouble to walk, including climbing slopes, those things. I have a hard time to go to the UBS, only if I really need and there is nobody to go, then I have to go. (male user)

[...] I stopped measuring my diabetes because my son, he was the one who used to go there and change the material, he did not go anymore, the tapes were over, everything was over, then I didn't measure it anymore. (male user)

[...] I went there to check if I could do it for free; I tried for free here at the health service in Diadema, but it was too much paper work, I couldn't, I had to pay for a biopsy. (male user)

[...] I'll see if I can get a report because he completed five years old, soon will be six, seven, then he will not want to do the surgery. He gets scared, gets scared. He has to do the phimosis surgery and until today. I even stopped going there. (female user)

[...] My medical chart went to the Vila Império. From Vila Império, I don't know if it stayed there, if it is there or if the chart went somewhere else. I don't think so, because after I moved from where I used to live I did not go to Vila Império anymore. (male user)

[...] there are times when I look for the UBS, but for weighting, looking for something that they have to do, vaccination (female user)

[..] I checked the temperature; it was 39 Celsius degrees of fever. I took him to the General Hospital Pedreira; the doctor said he had a beginning of throat infection [...] (female user)

$[\ldots]$ it is with the AMA that I go to UBS, inside it. (female user)

[...] allergic reaction we cannot take to the UBS...I thought it was better to take straight to the hospital in Pedreira. (female user)

\section{DISCUSSION}

The city of São Paulo is organized in Health Coordination Regions (HCR) and it is its role to perform the SUS management functions. Each HCR is formed by a defined number of sub city halls, and the South Coordination is composed by Campo Limpo, Capela do Socorro, Cidade Ademar, M'Boi Mirim, Parelheiros ans Santo Amaro sub city halls ${ }^{(16)}$.

The municipal assistance network from Ademar City micro region is composed by the following units or health services: Health Basic Units (UBS) that works in a traditional model as well as in the Family Health Strategy (ESF); the Specialty Ambulatory (AE); the Ambulatory Medical Assistance (AMA); the Special Ambulatory Medical Assistance 
(AMAE); the Domiciliary Assistance Unit (UAD); CAPES II; Odontology Specialized Center; the Elderly Health Reference Unit (URSI); the Support to Family Health Strategy Nucleus (NASF) and the Rehabilitation Integrated Nucleus (NIR and NIR2)(17). This micro region still counts with the HGP that is part of the São Paulo State Health Secretary.

Regarding the primary care, the traditional UBS are open to the public from $7 \mathrm{am}$ to $5 \mathrm{pm}$ and they are responsible for consultations, home visits; collective actions, procedures and health vigilance actions. Some of them work as AMA in the same structure, with amplified attending schedule until $7 \mathrm{pm}^{(18)}$. The access to these units happens with appointment scheduling at the reception; therefore, it was a spontaneous demand attendance.

For the UBS with the ESF, the access is viable in three ways: by the community health agent ( $\mathrm{CHA})$ that when meeting and visiting the family under his responsibility, identify the community demands and take them to a team meeting, through an Educational Assisted Group and Resolute in the Area, that is constituted by a group of patients' complaints qualifications that works through meetings done by the team with the community; and through the reception team (spontaneous demand) ${ }^{(18)}$.

In terms of work process, the ESF professionals do the same activities developed by the professionals who works in the traditional UBSs, with the difference that the first attend based in the population referred to its coverage area $^{(18)}$. This condition presupposes a distinct link with the population, resulting in more knowledge of their life and health conditions, and consequently their needs, with correspondent team responsibility.

When verifying the conditions to access the primary care services, major difficulties was observed in the users speeches. For the elderly group, this difficulty is aggravated by the limitation factor is the stronger limitation to go to the UBS, especially when there are no services close to their home, besides the dependence on a carer to help the disease control at home, in accordance with speech.

It is important to note in accordance with information from the Santa Catarina Social Organization, responsible for the management of the units at the time when the study was conducted, the elderly access to the UBS is similar to the access for other users and they have priority of attention depending on the case.

The micro region specialty ambulatory is responsible for the scheduled attendance in medical and non-medical specialties with referenced demand from other units which compose the health services net. The access for specialty consultation in the area belonging to the family health team is done with a solicitation from the UBS physician.

The users related difficulties to schedule appointments and to do specialty consultations and exams, besides dif- ficulty to do elective surgery. There were situations where the patient had to go for a private service (paid) to do the exams quicker, in accordance with the speech.

The difficulty to do the exams and specialty consultations are part of major barriers for the work of the APS teams, as it produces a barrier to the attention continuation. This situation is noted in the analysis of the situation done with base on the managers and health professionals' speech. Still in relation to the situation analysis, it was identified fragilities in the reference system and counterreference that negatively happen in the principles of integrality and the assistance continuation, recurrent from an excessive concentration of medium and high complexity in a unique point of the system and detached from the APS ${ }^{(19)}$.

The micro region from the City of Ademar does not count as a regulator center in the area, or of the municipally scope that attends it. The communication for scheduling and consultation referrals, exams and elective surgeries are done between services by the people from the management sector. This way, many times the patient does not understand how the health system is organized and where he should go for a solution of his problems, which constitutes an access barrier.

A study conducted in four brazilian cities points out the attention net integration from the APS to the specialized and hospital, was a present preoccupation in the managers actions and speeches, and the regulation centrals implantation one of the main strategies identifies for this integration ${ }^{(20)}$.

Those centrals implantations made possible some of those aspects: immediate scheduling for exams and special consultations for procedures with enough offer; clinical priorities definition; reduction of absence in special consultations; reduction in lines and waiting time; possibility of redistribution quotas between health centers; more impartiality in the agenda control ${ }^{(20)}$.

As previously referred, the network integration is fundamental to promote the attention integrality at the same time that is assures the APS continuity in the other levels of attention.

However, the integrality needs to be worked in diverse dimensions, thus it should be the result of efforts and confluence of knowledge from a multi professional team, in the concrete and singular space of health services, which would focus integrality, and the broaden integrality that is, the net articulation, institutionally, intentionally, procedural, of the multiple focused integrality which, having as epicenter each health service, are articulated in flows and circuits, from the real needs of people: one is not possible without the other, therefore existing a complementary and dialectic relationship ${ }^{(21)}$.

Although it is clearly defined the UBS mission including the low complexity aggravation resolution, according 
to SMS/SP data, in $2005,80 \%$ of urgency and emergency services demand of municipal public hospitals were due to this kind of problem ${ }^{(22)}$.

Facing this reality, considering the need to rationalize and prioritize the health services offer, amplifying the population access to the primary care, through the offer of services that allow agile answers to immediate medical assistance needs, the SMS/SP implemented the AMA units, integrated and articulated to the net services ${ }^{(22)}$.

Those units should be responsible for immediate medical assistance offer without previous scheduling, guaranteeing the patient's flow to the high complexity levels when needed. On the other side, those units are compromised to direct the users in need of UBS monitoring ${ }^{(17)}$.

In the speeches, it is clear their option of having the hospital or AMA as preferred entrance door to the system, over the UBS. For some, the UBS is understood as a place for simple things, as to weight or vaccinate children; that is, they perceive it as a limited field for health promotion and prevention of diseases and they do not recognize it as field com accompany and control diseases, including those more prevalent.

The lack of solution for UBS problems allied with the lack of understanding of how to organize a net of local health services, leads to, in the concrete presence of a illness, the municipalities search for higher complexity services, because besides the probable waiting time, it is higher the possibility of having your problem solved.

A study about the ICSAP with the APS professionals found that in some situations when the professional does not feel confident to diagnose in an opportune way the patient condition, he ends up sending him to the services where this attendance can be done quicker. This situation also contributes to the lack of credit from the population in relation to the UBS services ${ }^{(23)}$.

A SMS/SP assessment indicated an increase in the number of procedures in AMA with simultaneous reduction in the urgency/emergency procedures in the hospitals, probably reflecting the redirecting of flow and higher access to basic services to solve problems of lower complexity. In contradiction, this assessment showed that the increase in traditional procedures at AMA was accompanied with the decrease of the same activities at the traditional UBS(22).

The current SUS norm conception is of a one hierarchical pyramidal system, organized by relative complexities in each level of attention in APS, medium and high complexity. Still in agreement with this author, this conception is totally equivocated considering the dicionarized meaning, and not from the complexity theory, of something complicated and difficult, opposite of simple ${ }^{(24)}$.

In accordance with Mendes(24), for Cecílio ${ }^{(21)}$ it is nec- essary to think the health system less as a rationally organized services pyramid, organized in a hierarchical way and more as a net with multiple entrances, multiple flows, for which construction, the representations and individual needs are very important.

A study conducted in brazilian municipalities points out advances in the ESF integration to the assistance net, propitiating the basic services strengthening as services of regular pursuit and preferential entrance door, although barriers in special attention remains ${ }^{(20)}$.

In what the difficulty of population access to health services evidences, it is worthy the register of high quantity and diversity of health equipment in the micro region of Ademar. However, as the offer of services does not guarantee the access, difficulties remain for users, as found in the present study.

The health systems can get organized in a continuum that goes from fragmentation to integration and the fragmented systems tends to turn to the main care of conditions and acute events, while the integrated systems tends to act balanced on acute and chronic conditions ${ }^{(24)}$.

Remaining as Cecílio ${ }^{(21),}$ the fragmented, strongly hegemonic systems, even in Brazil, are organized by a conjunct of attention points, isolated and non-communicating within them, in a vision of a hierarchical pyramidal structure, incapable of attend continuously the population. On the other hand, the integrated systems are organized by a conjunct of coordinated health attention points for continuous and integral assistance to a defined population ${ }^{(24)}$.

Even considering that are distinct definition of access quoted by diverse authors, when adopting the Fekete ${ }^{(25)}$ terminology, this study found in the speeches that there are access problems considering the four dimensions studied by this author: geographical, organizational, socio-cultural and economic, in the micro region of Ademar.

Still, regarding the access, one of the main actual guidelines from the Health Ministry (MS) is to execute the public management based in the induction, monitoring and assessment of measurable processes, to guarantee access and quality in health care to the whole population. This way, the MS have been proposing many initiatives, within those it is highlighted the National Program to Enhance Access and Quality from (PMAQ), published in 2011, that has within other objectives, to stimulate the Basic Attention ( $A B$ ) focus in the user, promoting management transparency and process; participation and social control; and sanitary responsibility of professionals and health managers with the enhancement of health conditions and users' satisfaction ${ }^{(26)}$.

The results of the present study found at least in part, the challenges that the PMAQ pretends to face to the qualification of the basic attention, in respect of ambience poor welcoming from the Basic Health Units, passing the
Primary Care Sensitive Hospitalization: users detect flaws on the access to services Rehem TCMSB, Ciosak SI, Egry EY 
impression to the users that the services are low quality and negatively directed to poor populations; few integration from the $A B$ teams with the diagnostic and therapeutic support net and with other attention points in the Health Attention Net; and low integrity and resolution of practices $^{(26)}$.

\section{CONCLUSION}

The health system organization from the City of São Paulo, more specifically in this study case, in the micro region of the City of Ademar, in a hierarchical and pyramidal way, consequently with lack of integration between the diverse points of attention, can be one of the important aspects for the access matter, constituted as restriction factor to the role of the APS in reducing or even stopping the occurrence of the ICSAP.

This suspect is based not only in the analysis, even though superficial, of how the local net of attention is organized, but mainly in their speeches, demonstrating that the APS is not the preferred entrance door in the system, for its access barrier or for the lack of resolution in its actions.

Although the number of interviewed users is a limiting factor, mainly due to the long period between the hospitalization and interview, it came out problems that

\section{REFERENCES}

1. Organização Pan-Americana da Saúde. A Atenção à Saúde Coordenada pela APS: construindo as redes de atenção no SUS. Organização Pan-Americana da Saúde. Brasília;2011.

2. Brasil. Conselho Nacional de Secretários de Saúde. Planificação da Atenção Primária à Saúde nos Estados. CONASS. Brasília; 2011

3. Brasil. Ministério da Saúde. Secretaria de Atenção à Saúde. Departamento de Atenção Básica. Política Nacional de Atenção Básica. Ministério da Saúde. Brasília; 2012.

4. Brasil. Conselho Nacional de Secretários de Saúde. Seminário Internacional Atenção Primária à Saúde: Acesso Universal e Proteção Social. CONASS DOCUMENTA 27. Brasília; 2013.

5. Brasil. Ministério da Saúde. Secretaria de Vigilância em Saúde. Departamento de Análise de Situação de Saúde. Plano de ações estratégicas para o enfrentamento das doenças crônicas não transmissíveis no Brasil 2011-2022. Ministério da Saúde. Brasília; 2011.

6. Brasil. Ministério da Saúde. Portaria n. 221, de 17 abril de 2008. Publica em forma do anexo a lista brasileira de internações por condições sensíveis à atenção primária. Diário Oficial da União, Poder Executivo, Brasília. 21 set. Seção 1:50;2008. deserved a Program specific to Enhance the Quality and Access of Basic Attention, the PMAQ.

Although it is undeniable the SUS advances regarding the universality principle by the enlargement of access, especially to low income populations, it is undeniable that there are still barriers to the access for health services. This difficulty it's a bit smaller in the APS and it is amplified as the level of complexity of attention is increased.

However, the SUS does not have any information system capable of assessing the repressed demand to health services and even less capable to note barriers of populations dependent of the public health system.

Thereby, this study clearly demonstrates the importance of adopting a qualitative approach to study the ICSAP, to learn about the difficulties from the population and then to subsidize APS managers and employees in discussions regarding effectiveness of SUS principles and guidelines.

\section{ACKNOWLEDGEMENTS}

To the Research Support Foundation of the State of São Paulo (FAPESP), for its financial support for this research.

To the Coordination for the Improvement of Higher Education Personnel (CAPES), for the doctorate scholarship.

7. Alfradique ME, Bonolo PF,Dourado I,Lima-Costa MF, Macinko J, Mendonça CS, Oliveira VB, Sampaio LFR, Simoni CD, Turci MP. Internações por condições sensíveis à atenção primária: a construção da lista brasileira como ferramenta para medir o desempenho do sistema de saúde (Projeto ICSAP Brasil). Cad Saúde Pública. 2009;25(6):1337-49.

8. Caminal Homar J, Casanova Matutano C. La evaluación de la atención primaria y las hospitalizaciones por ambulatory care sensitive conditions. Marco conceptual. Aten. Primaria. 2003;31(1):61-5.

9. Eggli Y, Desquins B, Seker E, Halfon P. Comparing potentially avoidable hospitalization rates related to ambulatory care sensitive conditions in Switzerland: the need to refine the definition of health conditions and to adjust for population health status. BMC Health Serv Res. 2014;14:25.

10. Basu J, Mobley LR, Thumula V. The small area predictors of ambulatory care sensitive hospitalizations: a comparison of changes over time. Soc Work Public Health. 2014;29(2):176-88.

11. Mendonça CS, Harzheim E, Duncan BB, Nunes LN, Leyh W. Trends in hospitalizations for primary care sensitive conditions following the implantation of family health teams in Belo Horizonte, Brazil. Health Policy and Planning. Jun 2011;1-8. 
12. Nedel FB, Facchini LA, Bastos JL, Martín-Mateo M. Conceptual and methodological aspects in the study of hospitalizations for ambulatory care sensitive conditions. Cien Saúde Colet. 2011;(16 Supl 1):1145-54.

13. Dias-da-Costa JS, Buttenbender DC, Hoefel AL, Souza LL. Hospitalizações por condições sensíveis à atenção primária nos municípios em gestão plena do sistema no Estado do Rio Grande do Sul, Brasil. Cad Saúde Pública. 2010;26(2):358-64.

14. Camargo BV. ALCESTE: um programa informático de análise quantitativa de dados textuais. In: Moreira ASP, Camargo BV, Jesuíno JC, Nóbrega SM, organizadores. Perspectivas teórico-metodológicas em representações sociais. João Pessoa: Ed. Universitária; 2005. p. 511-39.

15. Oliveira DC, Gomes AMT, Marques SC. Análise estatística de dados textuais: alguns princípios e uma aplicação no campo da saúde. In: Menin MSS, Shimizu AM, organizadores. Experiências e Representação Social: questões teóricas e metodológicas. São Paulo: Casa do Psicólogo; 2005.

16. São Paulo (Município). Decreto n. 45.037 de 20 de julho de 2004. Dispõe sobre a organização do Sistema Único de Saúde no Município de São Paulo. Diário Oficial do Município de São Paulo, São Paulo, 21 jul. 2004. Seção1:1-2.

17. São Paulo (Município). Secretaria Municipal da Saúde. Manual - Diretrizes técnicas da assistência médica ambulatorial na atenção básica. São Paulo [Internet] 2009 [cited 2011 maio 17]. Available from: http: www.prefeitura.sp.gov.br/ cidade/secretarias/upload/saúde/arquivos/ama/AMA_ManualDiretrizesTecnicas.pdf.

18. São Paulo (Município). Secretaria Municipal da Saúde. Associação Congregação de Santa Catarina. Contrato de gestão n. 005/2008 - NTCSS-SMS. Microrregião de Cidade Ademar. São Paulo: Prefeitura Municipal de São Paulo; 2008.

19. Brasil. Conselho Nacional de Secretários de Saúde. SUS 20 ANOS. CONASS. Brasília; 2009.
20. Giovanella L Mendonça MHM, Almeida PF, Escorel S, Senna MCM, Fausto MCR, et al. Saúde da família: limites e possibilidades para uma abordagem integral de atenção primária à saúde no Brasil. Rev C S Col. 2009;14(3):783-94.

21. Cecílio LCO. As necessidades de saúde como conceito estruturante na luta pela integralidade e equidade na atenção à saúde. In: Pinheiro R, Mattos RA, organizadores. Os sentidos da integralidade na atenção e no cuidado à saúde. Rio de Janeiro: Abrasco; 2001. p.113-27.

22. São Paulo (Município). Secretaria Municipal da Saúde. AMA especialidades: diretrizes técnicas. São Paulo. [Internet] 2009 [cited 2011 maio 17]. Available from: http: www.prefeitura.sp.gov.br/cidade/secretarias/upload/saúde/arquivos/ama/AMA_especialidades.pdf.

23. Rehem TCMSB. Internações Sensíveis à Atenção Primária: Limites e Possibilidades da Lista brasileira de Diagnósticos [tese de doutorado]. São Paulo: Escola de Enfermagem da Universidade de São Paulo; 2011.

24. E.V. Mendes. O Cuidado das Condições Crônicas na Atenção Primária à Saúde: o imperativo da consolidação da estratégia da saúde da família. Brasília: Organização Pan - Americana da Saúde ; 2012.

25. M.C. Fekete. Estudo da acessibilidade na avaliação dos serviços. Projeto GERUS. [S.I.: s.n.]; 1996.

26. Brasil. Ministério da Saúde. Departamento de Atenção Básica. Programa Nacional de Melhoria do Acesso e da Qualidade da Atenção Básica (PMAQ). Brasília [cited 2014 março 16]. Available from: http://dab.saude.gov.br/sistemas/ Pmaq/. 